TITLE:

\title{
The synthesis of [18F]pitavastatin as a tracer for hOATP using the Suzuki coupling.
}

\section{$\operatorname{AUTHOR}(\mathrm{S}):$}

Yagi, Yusuke; Kimura, Hiroyuki; Arimitsu, Kenji; Ono, Masahiro; Maeda, Kazuya; Kusuhara, Hiroyuki; Kajimoto, Tetsuya; Sugiyama, Yuichi; Saji, Hideo

\section{CITATION:}

Yagi, Yusuke ...[et al]. The synthesis of [18F] pitavastatin as a tracer for hOATP using the Suzuki coupling.. Organic \& biomolecular chemistry 2014, 13(4): 1113-1121

\section{ISSUE DATE:}

2014-11-13

URL:

http://hdl.handle.net/2433/198617

\section{RIGHT:}

(C) The Royal Society of Chemistry 2015; 許諾条件により本文ファイルは 2015-11-13に公開.; This is not the published version. Please cite only the published version.; この論文は出版社版でありません。引用の際に は出版社版をご確認ご利用ください。 


\section{The synthesis of $\left[{ }^{18}\right.$ F]pitavastatin as a tracer for hOATP using the Suzuki coupling}

Yusuke Yagi $^{\# a}$, Hiroyuki Kimura ${ }^{\# a, b, *}$, Kenji Arimitsu ${ }^{\mathrm{a}, \mathrm{c}}$, Masahiro Ono ${ }^{\mathrm{a}}$, Kazuya Maeda $^{\mathrm{d}}$, Hiroyuki Kusuhara ${ }^{\mathrm{d}}$, Tetsuya Kajimoto ${ }^{\mathrm{e}}$, Yuichi Sugiyama ${ }^{\mathrm{d}, \mathrm{f}}$ and Hideo Saji ${ }^{\mathrm{a}, *}$

${ }^{a}$ Department of Patho-Functional Bioanalysis, Graduate School of Pharmaceutical

Sciences, Kyoto University; 46-29 Yoshida Shimoadachi-cho, Sakyo-ku, Kyoto 606-8501, Japan

${ }^{b}$ Radioisotope Research Center of Kyoto University, Yoshida Konoe-cho, Sakyo-ku, Kyoto 606-8501, Japan

${ }^{c}$ School of Pharmaceutical Sciences, Mukogawa Women's University, 11-68 Koshien Kyubancho, Nishinomiya, Hyogo 663-8179, Japan

${ }^{d}$ Laboratory of Molecular Pharmacokinetics, Graduate School of Pharmaceutical

Sciences, The University of Tokyo; 7-3-1 Hongo, Bunkyo-ku, Tokyo 113-0033, Japan

${ }^{e}$ Research Organization of Science and Technology, Research Center for Drug

Discovery and Pharmaceutical Development Sciences, Ritsumeikan University, 1-1-1, Noji-higashi, Kusatsu, Shiga 525-8577, Japan 
${ }^{f}$ Sugiyama Laboratory, RIKEN Innovation Center, RIKEN Research Cluster for

Innovation, RIKEN, 1-7-22 Suehiro-cho, Tsurumi-ku, Yokohama, Kanagawa, 230-0045,

Japan

*Corresponding authors

Hideo Saji, PhD

Tel: +81-75-753-4556; Fax: +81-75-753-4568; E-mail: hsaji@pharm.kyoto-u.ac.jp

Hiroyuki Kimura, $\mathrm{PhD}$

E-mail: hkimura@pharm.kyoto-u.ac.jp

\#These authors contributed equally to this work 


\section{Table of Contents/Graphical Abstract}

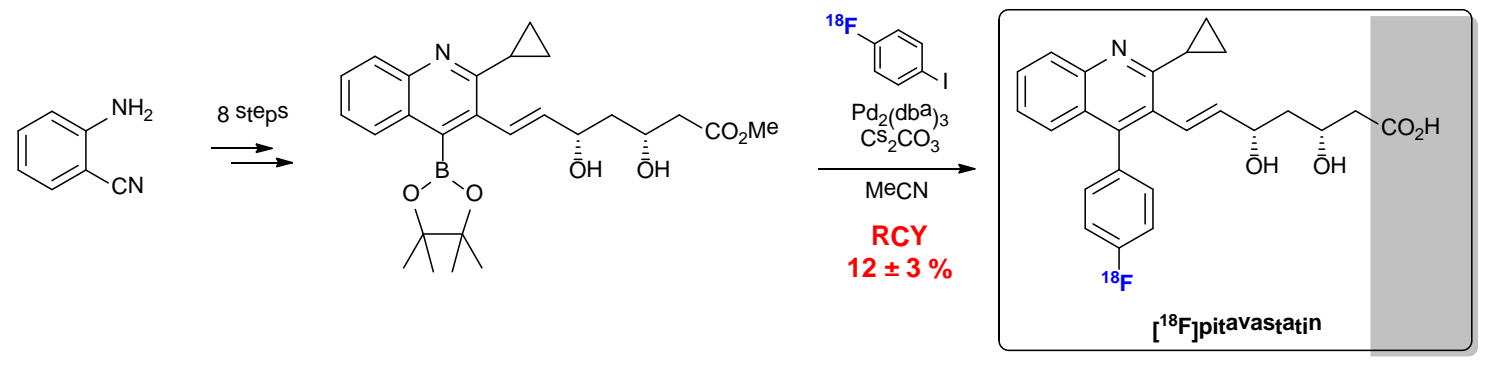

\section{$\underline{\text { Abstract }}$}

Fluorine-18 labeled radiotracers, such as $\left[{ }^{18} \mathrm{~F}\right]$ fluorodeoxyglucose, can be used as practical diagnostic agents in positron emission tomography (PET). Furthermore, the properties of pharmaceuticals can be enhanced significantly by the introduction of fluorine groups into their original structures, and significant progress has been made during the last three decades towards the development of practical procedures for the introduction of fluorine. The replacement of the fluorine atoms present in pharmaceuticals with radioactive ${ }^{18} \mathrm{~F}$ atoms is a rational approach for designing novel PET tracers. As a fluorine-containing pharmaceutical agent, pitavastatin has attracted considerable interest from researchers working in the life sciences because it can act as an antihyperlipidemic agent as well as being a substrate for hepatic organic anion transporting polypeptides (hOATP). With this in mind, it was envisaged that $\left[{ }^{18} \mathrm{~F}\right]$ pitavastatin would be used an excellent imaging agent for hOATP, which prompted us to investigate the synthesis of this agent. Herein, we report a practical method for the 
synthesis of $\left[{ }^{18} \mathrm{~F}\right]$ pitavastatin by the Suzuki coupling reaction of $p$-iodofluorobenzene and a quinoline boronate derivative, with the desired product being formed in a radiochemical yield of $12 \pm 3 \%$ (decay corrected from $\left[{ }^{18} \mathrm{~F}\right]$ fluoride ion, $n=3$ ). 


\section{Introduction}

Positron emission tomography (PET) is an imaging technique that is mainly used for the diagnosis of diseases such as cancer and Alzheimer disease, although this technique can also be used for the evaluation of innovative therapies and drugs. ${ }^{[1]}$ A large number of radiotracers have been developed to date using ${ }^{18} \mathrm{~F}$, such as $\left[{ }^{18} \mathrm{~F}\right]$ fluorodeoxyglucose $\left(\left[{ }^{18} \mathrm{~F}\right] \mathrm{FDG}\right),{ }^{[1 \mathrm{a}]}\left[{ }^{18} \mathrm{~F}\right]$ Florbetapir $\left(\left[{ }^{18} \mathrm{~F}\right] \mathrm{AV}-45\right),{ }^{[1 \mathrm{~b}, \mathrm{c}]}\left[{ }^{18} \mathrm{~F}\right]$ Flutemetamol $\left(\left[{ }^{18} \mathrm{~F}\right] \mathrm{GE}-067\right){ }^{[1 \mathrm{~d}]}$ and $\left[{ }^{18} \mathrm{~F}\right]$ Florbetaben $\left(\left[{ }^{18} \mathrm{~F}\right] \mathrm{BAY} 94-9172\right),{ }^{[1 \mathrm{e}]}$ because ${ }^{18} \mathrm{~F}$ has a much longer half-life (109.7 min) than most of the other positron emitting radionuclides commonly incorporated into pharmaceutical agents, such as ${ }^{11} \mathrm{C}(20 \mathrm{~min}),{ }^{13} \mathrm{~N}(10 \mathrm{~min})$ and ${ }^{15} \mathrm{O}(2$ min). The incorporation of ${ }^{18} \mathrm{~F}$ can also be much easier to achieve than the incorporation of other positron emitting radionuclides with longer half-lives such as ${ }^{124}$ I (4.2 days) and ${ }^{89} \mathrm{Zr}$ (78.4 h). Furthermore, a number of fluorine-containing pharmaceuticals have been developed during the course of the last three decades for use in clinical applications, where the fluorine groups were introduced to impart the appropriate physicochemical, drug metabolism and pharmacokinetics (DMPK) properties to the active agents. ${ }^{[2]}$ These agents could therefore be used as potential PET tracers by the replacement of their ${ }^{19} \mathrm{~F}$ atoms with radioactive ${ }^{18} \mathrm{~F}$ atoms without changing any of the chemical or biological properties of the parent pharmaceutical. In fact, several 
${ }^{18} \mathrm{~F}$-containing pharmaceutical have already been synthesized via the replacement of their ${ }^{19} \mathrm{~F}$ atoms with ${ }^{18} \mathrm{~F}$ atoms, including $\left[{ }^{18} \mathrm{~F}\right]$ flumazenil, ${ }^{[3 a, b]}\left[{ }^{18} \mathrm{~F}\right]$ xeloda ${ }^{[3 c]}$ and $\left[{ }^{18} \mathrm{~F}\right]$ spiperone,${ }^{[3 \mathrm{~d}]}$ which have all been used as tracers in PET imaging experiments.

Several DMPK studies have recently been reported pertaining to the use of PET imaging methods and tracers to develop a deeper understanding of hepatic organic anion transporting polypeptides (hOATP), which play an important role in the metabolism of drugs in the liver, and several candidate tracers were synthesized. ${ }^{[4]}$ Unfortunately, however, no tracers have been reported to date with potential clinical applications. The major difficulty associated with the development of tracers for hOATP is achieving selectivity for OATP1B1, which makes a significant contribution to hepatic uptake in humans, ${ }^{[4]}$ over OATP1B3. Fortunately, however, the fluorine containing antilipidemic agent pitavastatin ${ }^{[5]}$ is a selective substrate of OATP1B1 with a hepatic uptake clearance of less than $50 \%$ hepatic blood flow. It was therefore envisaged that $\left[{ }^{18} \mathrm{~F}\right]$ pitavastatin (Figure 1) could be used as a novel PET tracer of hOATP, and this prompted us to design a strategy for the synthesis of this compound.

Fluorine atoms have traditionally been incorporated into aromatic ring through electrophilic substitution reactions using fluorine gas. However, radiofluorination reactions using $\left[{ }^{18} \mathrm{~F}\right] \mathrm{F}_{2}$ gas typically afford fluorinated products with low levels of 
specific radioactivity (generally less than $0.40 \mathrm{GBq} / \mu \mathrm{mol}$ ) because the $\left[{ }^{18} \mathrm{~F}\right] \mathrm{F}_{2}$ used in these experiments is generally contaminated with non-radioactive $F_{2}$ as a carrier gas. ${ }^{[6]}$ Furthermore, the introduction of ${ }^{18} \mathrm{~F}$ atoms through nucleophilic aromatic substitution reactions using fluoride ions (e.g., the Balz-Schiemann reaction) requires challenging experimental procedures and generally affords low yields of the desired product (approximately $10 \%$ ) because fluoride ions are only weakly nucleophilic. ${ }^{[7]}$ Based on these limitations, there is an urgent need for the development of a new method for the synthesis of ${ }^{18} \mathrm{~F}$ labeled compounds. An alternative and reliable approach to the synthesis of ${ }^{18} \mathrm{~F}$ labeled compounds, which is referred to as the assembling approach, has recently been described. ${ }^{[8]}$ According to this approach, the pre-labeled unit can be connected to another intermediate through synthesis to provide facile access to the radiolabeled pharmaceutical agent. Herein, we report a novel method for the synthesis of $\left[{ }^{18} \mathrm{~F}\right]$ pitavastatin via the Suzuki coupling reaction ${ }^{[9]}$ of $p-\left[{ }^{18} \mathrm{~F}\right]$ fluoroiodobenzene with a boronate ester derivative of quinoline in the presence of a palladium catalyst.

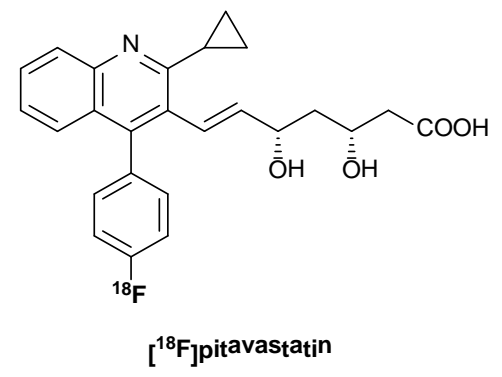

Figure 1. Structure of $\left[{ }^{18} \mathrm{~F}\right]$ pitavastatin 


\section{$\underline{\text { Results and Discussion }}$}

Any potential new route for the synthesis of $\left[{ }^{18} \mathrm{~F}\right]$ pitavastatin would need to introduce the ${ }^{18} \mathrm{~F}$ atom during the latter stages of the process because of the short half-life of ${ }^{18} \mathrm{~F}$ (109.7 min). For this reason, it was not possible to apply a previously reported route ${ }^{[10]}$ for the synthesis of $\left[{ }^{18} \mathrm{~F}\right]$ pitavastatin because this method would have required the introduction of ${ }^{18} \mathrm{~F}$ during the early stages of the synthesis (Scheme 1 ). The decision was therefore taken to establish a novel synthetic route to $\left[{ }^{18} \mathrm{~F}\right]$ pitavastatin, where the ${ }^{18} \mathrm{~F}$ atom would be incorporated at the latter stages of the synthesis.<smiles>Nc1ccccc1-c1ccc(F)cc1</smiles>
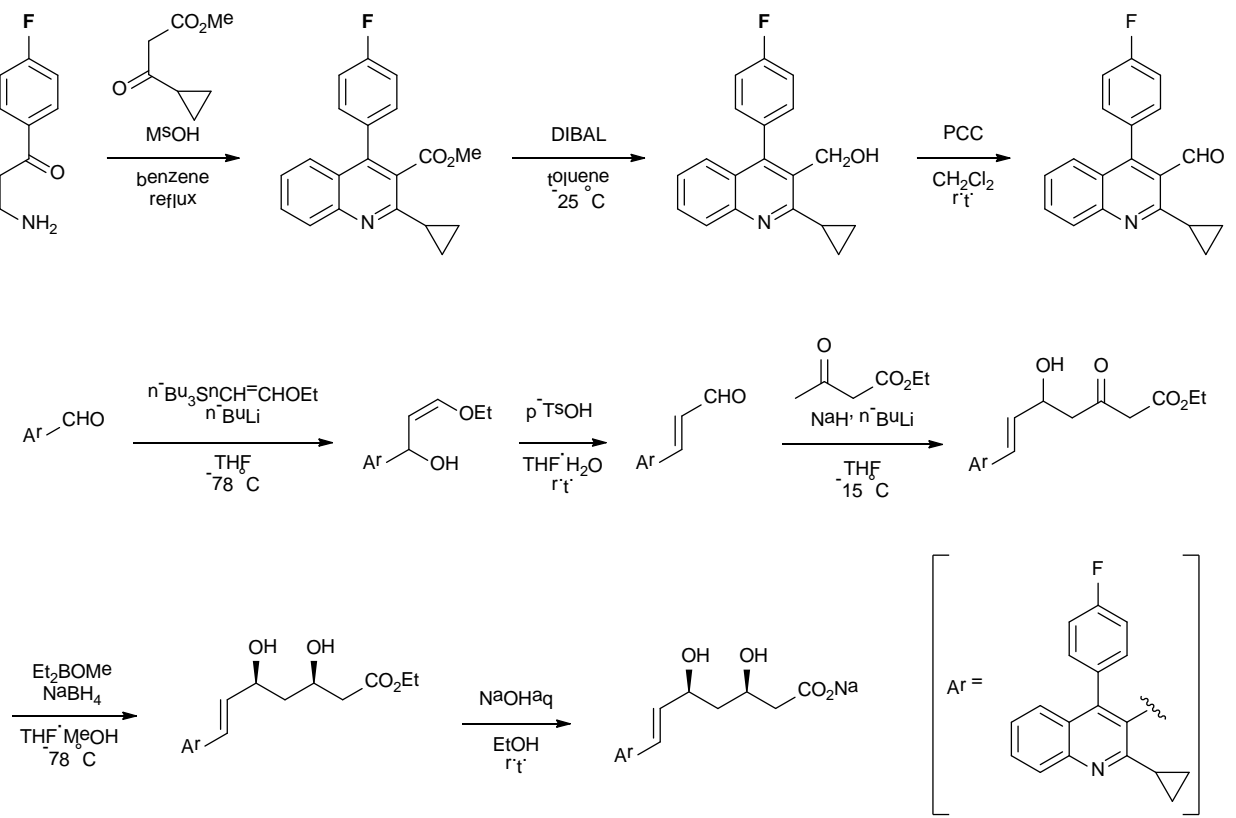

Scheme 1. Previously reported synthetic route of pitavastatin ${ }^{[10]}$ 
It was envisaged that the required ${ }^{18} \mathrm{~F}$ atom could be introduced via a Suzuki coupling reaction between $p$ - $\left[{ }^{18} \mathrm{~F}\right]$ fluoroiodobenzene $\left(\left[{ }^{18} \mathrm{~F}\right] \mathbf{1}\right)$ and boronate $\mathbf{2}$ in the presence of a palladium catalyst (Scheme 2). Compound $\left[{ }^{18} \mathrm{~F}\right] \mathbf{1}$ was prepared by the nucleophilic aromatic substitution reaction of 4-iodophenyldiphenylsulfonium triflate with a $\left[{ }^{18} \mathrm{~F}\right]$ fluoride ion. Retrosynthetic analysis of boronate 2 revealed that this material could be synthesized from aldehyde 4, which could undergo a Horner-Wadsworth-Emmons reaction in the forward sense with phosphonate 3 to give boronate 2. ${ }^{[10 \mathrm{a}]}$ Aldehyde 4 could itself be generated from 2-aminobenzonitrile (5) through a series of transformations involving a quinoline formation with an appropriately functionalized $\beta$-keto ester.

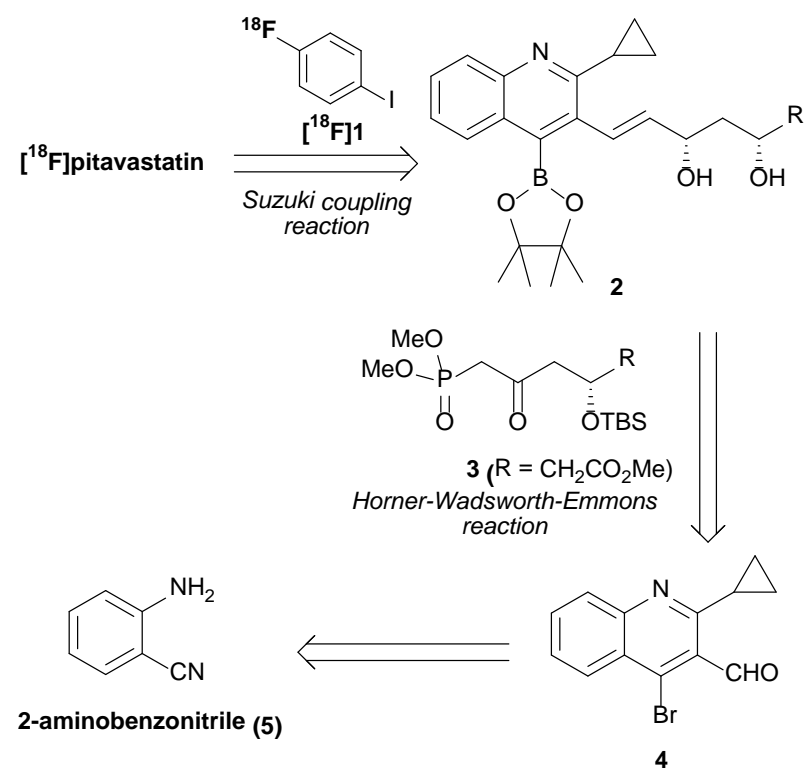

Scheme 2. Retrosynthesis of $\left[{ }^{18} \mathrm{~F}\right]$ pitavastatin 
The Friedlander reaction ${ }^{[11]}$ of 2-aminobenzonitrile (5) with $\beta$-keto ester 6 was performed in the presence of tin (IV) chloride to give aminoquinoline $\mathbf{7}$ in good yield (Scheme 3). The amino group of compound 7 was converted to the corresponding diazonium salt, which was subjected to a Sandmeyer reaction with copper (I) bromide to give aryl bromide $\mathbf{8}$. Subsequent reduction of the methyl ester group in $\mathbf{8}$ with diisobutylaluminium hydride (DIBAL) gave alcohol 8a, which was oxidized with Dess-Martin periodinane (DMP) to give aldehyde 4.

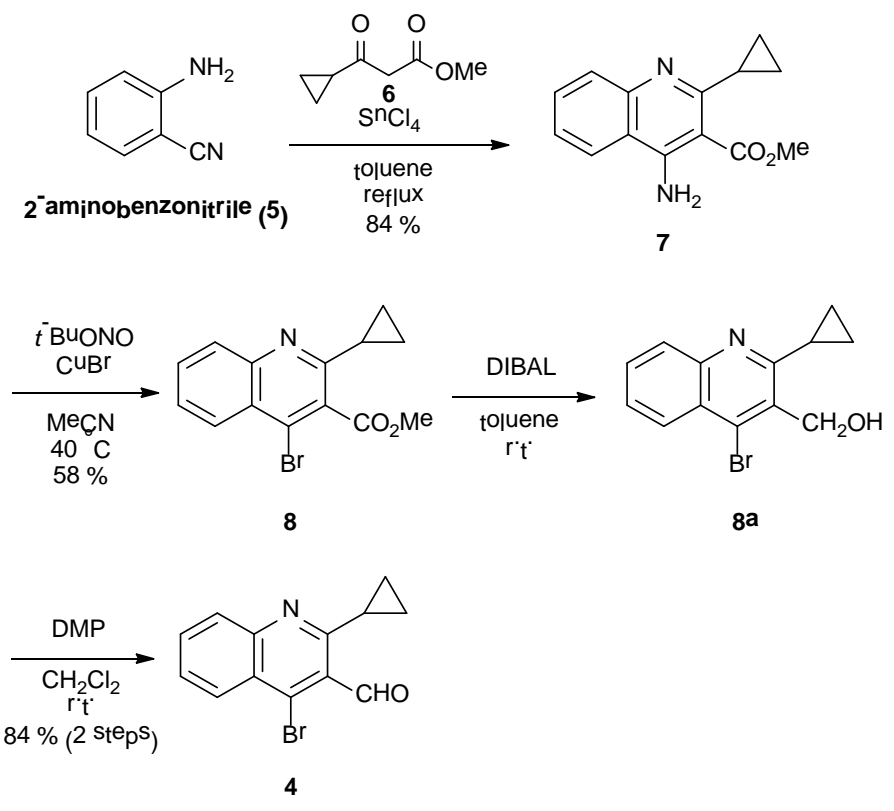

Scheme 3. Synthesis of the aldehyde 4

The treatment of aldehyde $\mathbf{4}$ with phosphonate $3^{[12]}$ yielded the desired $(E)$-alkene $\mathbf{9}$ in excellent yield (Scheme 4). Unfortunately, however, the ester group in 9 underwent 
an undesired hydrolysis reaction during the removal of the tert-butyldimethylsilyl group with tetrabutylammonium fluoride (TBAF). To avoid the undesired hydrolysis of the methyl ester, alkene 9 was treated with diluted hydrofluoric acid in MeCN to afford $\beta$-hydroxy ester $\mathbf{1 0}$ in $89 \%$ yield. Stereoselective reduction of the carbonyl group with diethylmethoxyborane and sodium borohydride gave the desired diol $\mathbf{1 1}$ as a single diastereomer. The subsequent reaction of diol 11 with bis(pinacolato)diboron (12) in the presence of a palladium catalyst gave boronate $\mathbf{2}$, which was the precursor to the Suzuki coupling, in $26 \%$ yield.
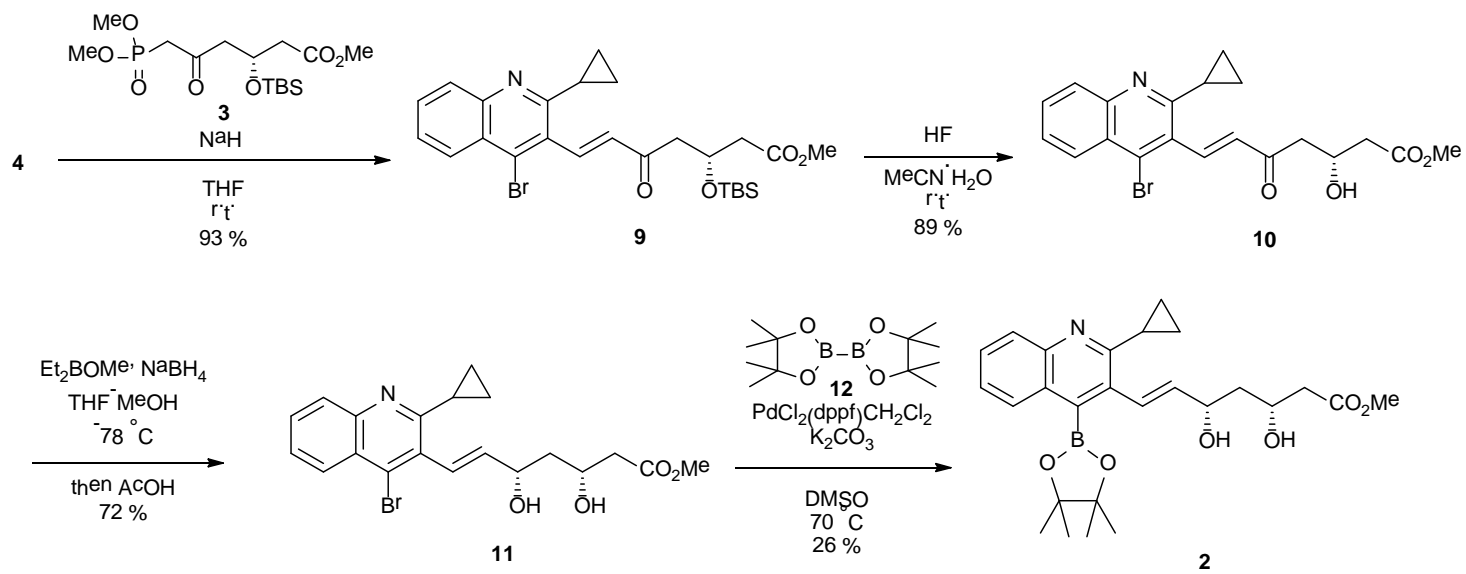

Scheme 4. Synthesis of boronate 2

The Suzuki coupling of $\mathbf{1}$ with $\mathbf{2}$ was investigated under a variety of different reaction conditions to determine the best catalyst for the transformation (Table 1). When 
the reaction was performed in the presence of $\mathrm{Pd}\left(\mathrm{PPh}_{3}\right)_{4}$ and $\mathrm{Na}_{2} \mathrm{CO}_{3}$ in dimethylsulfoxide (DMSO) at $90{ }^{\circ} \mathrm{C}$, only a trace amount of the desired product $\mathbf{1 3}$ was obtained (Table 1, entry 1). Similar poor results were also obtained when $\mathrm{PdCl}_{2}(\mathrm{dppf}) \mathrm{CH}_{2} \mathrm{Cl}_{2}$ or $\mathrm{Pd}\left(\mathrm{PPh}_{3}\right)_{2} \mathrm{Cl}_{2}$ were used as the catalyst (Table 1, entries 2 and 3). In contrast, the use of $\mathrm{Pd}(\mathrm{OAc})_{2}$ in the presence of $\mathrm{PPh}_{3}$ gave a slightly better yield of the desired product (Table 1, entry 4). Pleasingly, the use of a combination of $\operatorname{Pd}\left(\mathrm{PPh}_{3}\right)_{4}$ and $\mathrm{PdCl}_{2}(\mathrm{dppf}) \mathrm{CH}_{2} \mathrm{Cl}_{2}$ or $\mathrm{Pd}_{2}(\mathrm{dba})_{3}$ alone yielded the coupling product in 50 and $63 \%$ yields, respectively. These results therefore demonstrated that we had successfully established a novel route for the synthesis of pitavastatin, which could be used for the synthesis of $\left[{ }^{18} \mathrm{~F}\right]$ pitavastatin (Scheme 5). 
Table 1. Suzuki coupling reaction of boronate $\mathbf{2}$ with $\mathbf{1}^{\text {a }}$

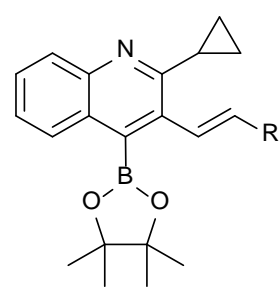

2

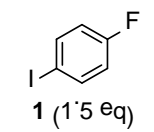

catalyst (10 mol\%)

$\underset{\text { con }}{\stackrel{\mathrm{Na}_{2} \mathrm{CO}_{3}\left(3^{\circ} \mathrm{O}_{\mathrm{q}}\right)}{\longrightarrow}}$

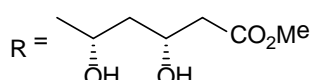

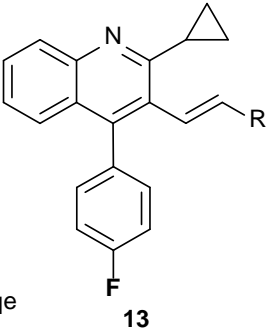

13

Conditions

Entry Catalyst

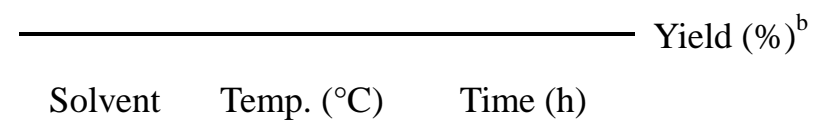

Solvent $\quad$ Temp. $\left({ }^{\circ} \mathrm{C}\right) \quad$ Time $(\mathrm{h})$

\begin{tabular}{|c|c|c|c|c|c|}
\hline 1 & $\mathrm{Pd}\left(\mathrm{PPh}_{3}\right)_{4}$ & DMSO & 90 & 9 & $<10$ \\
\hline 2 & $\mathrm{PdCl}_{2}(\mathrm{dppf}) \mathrm{CH}_{2} \mathrm{Cl}_{2}$ & DMSO & 90 & 9 & $<10$ \\
\hline 3 & $\mathrm{Pd}\left(\mathrm{PPh}_{3}\right)_{2} \mathrm{Cl}_{2}$ & DMSO & 90 & 9 & $<10$ \\
\hline 4 & $\mathrm{Pd}(\mathrm{OAc})_{2} / \mathrm{PPh}_{3}$ & DMSO & 90 & 9 & 29 \\
\hline 5 & $\mathrm{Pd}\left(\mathrm{PPh}_{3}\right)_{4} / \mathrm{PdCl}_{2}(\mathrm{dppf}) \mathrm{CH}_{2} \mathrm{Cl}_{2}$ & DMSO & 90 & 9 & 50 \\
\hline 6 & $\mathrm{Pd}_{2}(\mathrm{dba})_{3}$ & DMSO & 90 & 9 & 63 \\
\hline
\end{tabular}

${ }^{\mathrm{a}}$ 2: $0.08 \mathrm{mmol}$, solvent: $1.0 \mathrm{~mL} .{ }^{\mathrm{b}}$ Yield was determined from LC-MS.

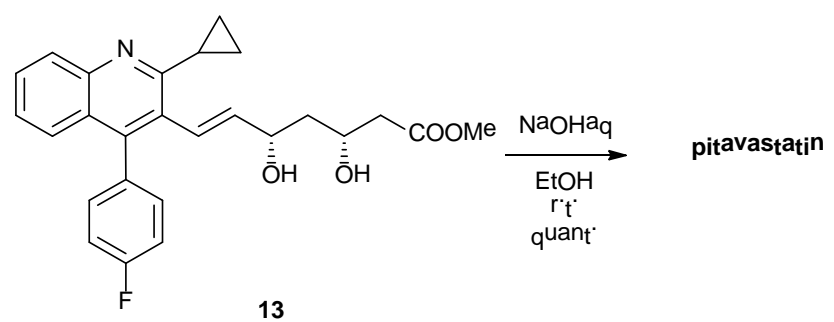

Scheme 5. Synthesis of pitavastatin 
With our newly developed route in hand, we proceeded to investigate the synthesis of $\left[{ }^{18} \mathrm{~F}\right] \mathbf{1}$ so that it could be used to complete the synthesis of the target molecule, $\left[{ }^{18} \mathrm{~F}\right]$ pitavastatin. Compound $\left[{ }^{18} \mathrm{~F}\right] \mathbf{1}$ was synthesized according to the Lehmann method. ${ }^{[13]}$ Namely, a mixture of 4-iodophenyldiphenyl-sulfonium triflate, $\left[{ }^{18} \mathrm{~F}\right] \mathrm{KF}$ and $\mathrm{K}_{2} \mathrm{CO}_{3}$ in $\mathrm{MeCN}$ was heated under microwave irradiation at $120{ }^{\circ} \mathrm{C}$ in the presence of Kryptofix2.2.2 to give the desired product with a radiochemical yield (RCY) of $56 \pm 3 \%$ (Scheme 6).

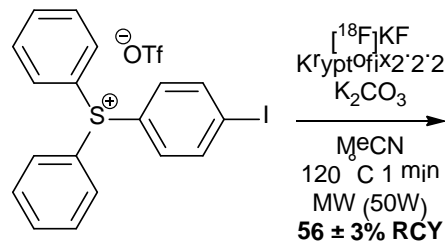<smiles>[PH3+]c1ccc(I)cc1</smiles>

Scheme 6. Synthesis of $\left[{ }^{18} \mathrm{~F}\right] \mathbf{1}$ from 4-iodophenyldiphenylsulfonium triflate

The Suzuki coupling reaction of $\left[{ }^{18} \mathrm{~F}\right] \mathbf{1}$ with boronate $\mathbf{2}$ was investigated under a variety of different conditions to identify the optimum conditions for the transformation (Table 2). Considering the relatively short half-life of ${ }^{18} \mathrm{~F}$, the heating time was limited to 10 min. Moreover, the reaction was performed in a tightly sealed tube, which was heated on a heating block at $100{ }^{\circ} \mathrm{C}$ to avoid the spread of the radioisotope in the surrounding area. Unfortunately, the optimum reaction conditions developed above for 
the Suzuki reaction of unlabeled 1 (i.e., DMSO, $\mathrm{Pd}_{2}(\mathrm{dba})_{3}$ and $\mathrm{Na}_{2} \mathrm{CO}_{3}$ ) were not suitable for the synthesis of the radioactive compound. Changing the solvent from DMSO to dimethylformamide (DMF) or MeCN had very little impact on the outcome of the reaction, with the product being obtained in low yield (Table 2, entries 2 and 3). Pleasingly, the use of $\mathrm{Cs}_{2} \mathrm{CO}_{3}$ instead of $\mathrm{Na}_{2} \mathrm{CO}_{3}$ led to an increase in the yield of the product (Table 2, entries 4-6). It is noteworthy that the methyl ester in $\left[{ }^{18} \mathrm{~F}\right] \mathbf{1 3}$ underwent a spontaneous hydrolysis reaction following the coupling reaction or during the work-up procedure to yield $\left[{ }^{18} \mathrm{~F}\right]$ pitavastatin when $\mathrm{Cs}_{2} \mathrm{CO}_{3}$ was used as the base. In practice, the optimum conditions for the coupling reaction were determined to be $\mathrm{Pd}_{2}(\mathrm{dba})_{3}$ and $\mathrm{Cs}_{2} \mathrm{CO}_{3}$ in $\mathrm{MeCN}$ at $100{ }^{\circ} \mathrm{C}$ for $10 \mathrm{~min}$ (Table 2, entry 9). The conditions gave $\left[{ }^{18} \mathrm{~F}\right]$ pitavastatin in a chemical yield of $63 \pm 2 \%$ and a RCY of $28 \pm 3 \%$ following purification by RP-HPLC. 
Table 2. Synthesis of $\left[{ }^{18} \mathrm{~F}\right]$ pitavastatin by the Suzuki coupling of boronate 2 with $\left[{ }^{18} \mathrm{~F}\right] \mathbf{1}^{\mathrm{a}}$
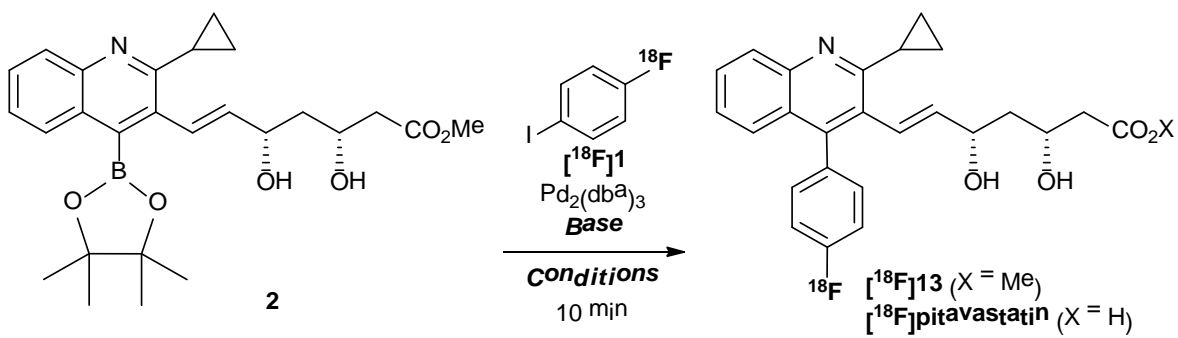

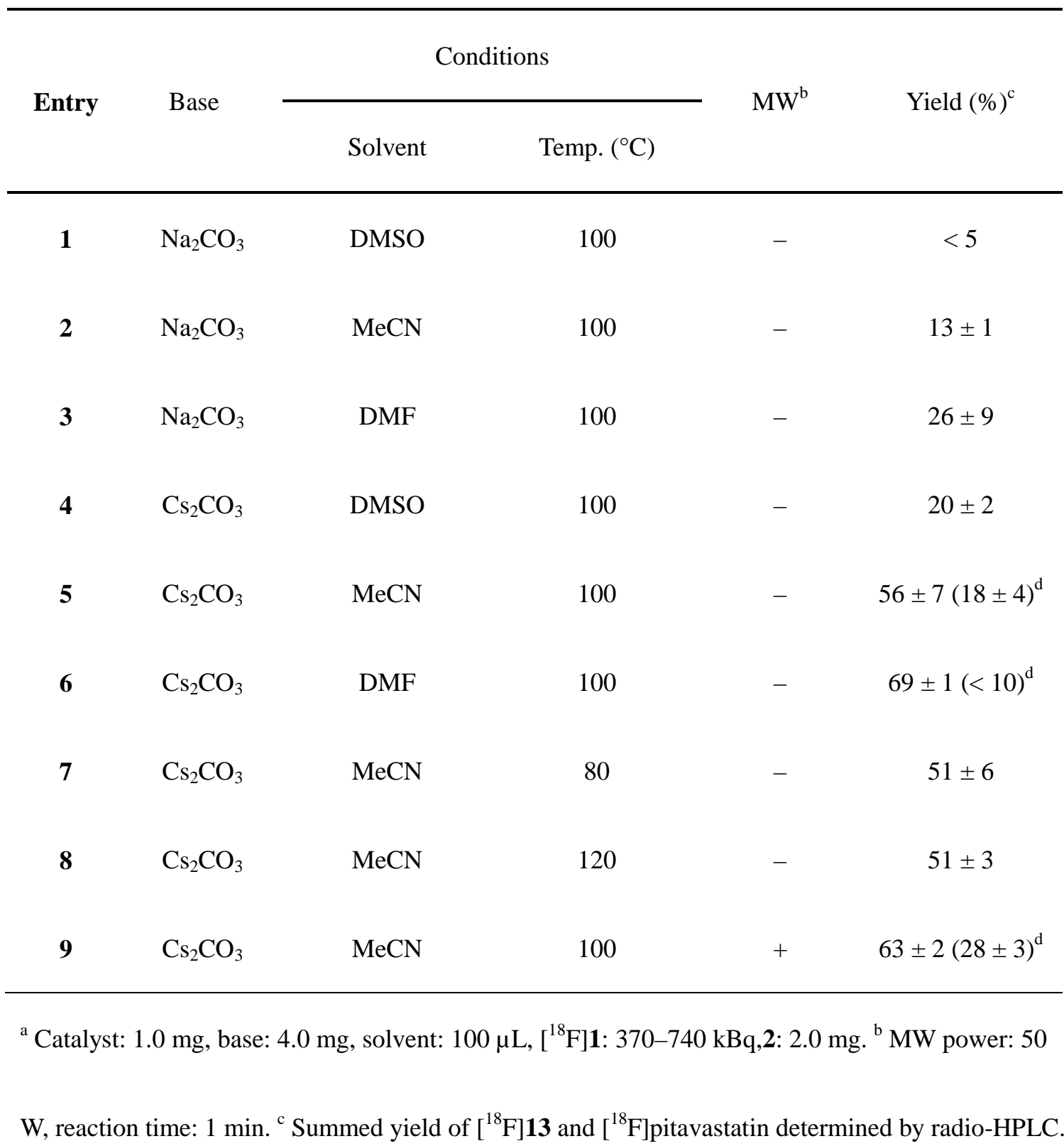


Data are the mean \pm S.D. $(n=3) .{ }^{\mathrm{d}}$ Isolated yield of $\left[{ }^{18} \mathrm{~F}\right]$ pitavastatin (Radiochemical yield). All

reactions were carried out in a sealed reaction vessel on an aluminum block heater.

As a result, $\left[{ }^{18} \mathrm{~F}\right]$ pitavastatin was obtained in a radiochemical yield of $12 \pm 3 \%$ (decay corrected from $\left[{ }^{18} \mathrm{~F}\right]$ fluoride ion) (Scheme 7). The identity of the radiotracer was confirmed by RP-HPLC following its co-injection with the non-radiolabeled reference compound (Figure 2).

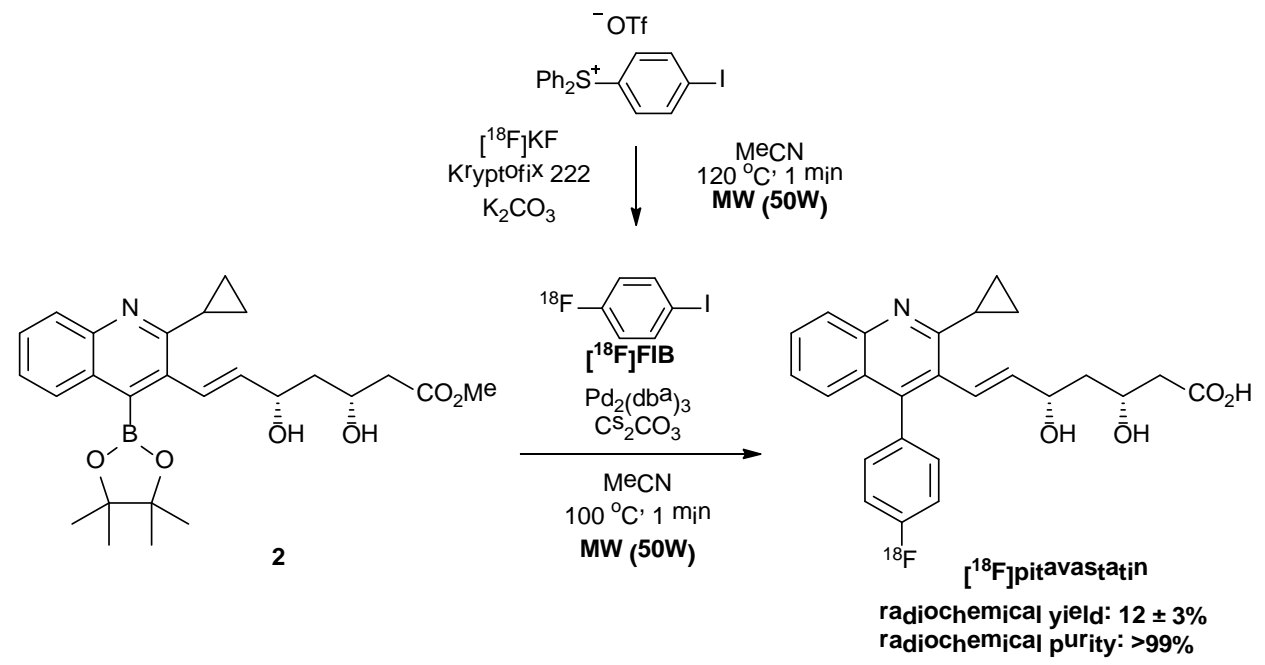

Scheme 7 Synthesis of $\left[{ }^{18} \mathrm{~F}\right]$ pitavastatin 

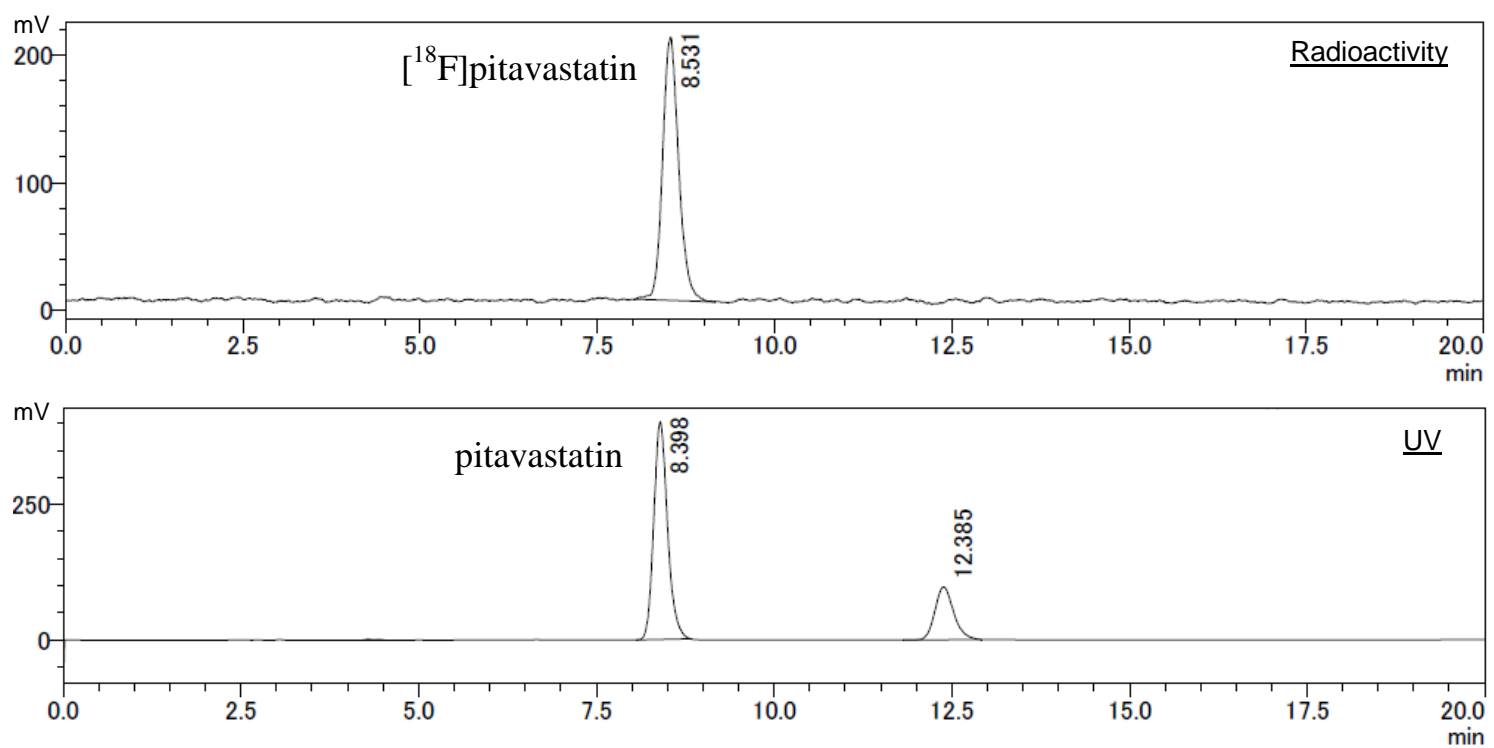

Figure 2. Analytical RP-HPLC chromatograms of $\left[{ }^{18} \mathrm{~F}\right]$ pitavastatin co-injected with non-radiolabeled pitavastatin. The UV spectra were recorded at $254 \mathrm{~nm}$. The peak at $12.385 \mathrm{~min}$ corresponds to the lactone derived from the intramolecular cyclization of pitavastatin. 


\section{Conclusion}

In summary, we developed a novel route for the synthesis of pitavastatin using a Suzuki coupling reaction as the key step to allow for the late stage incorporation of ${ }^{18} \mathrm{~F}$. Using this route, we successfully synthesized $\left[{ }^{18} \mathrm{~F}\right]$ pitavastatin in good yield by the Suzuki coupling of boronate 2 with $p-\left[{ }^{18} \mathrm{~F}\right]$ fluoroiodobenzene under microwave heating conditions in the presence of $\mathrm{Pd}_{2}(\mathrm{dba})_{3}$ and $\mathrm{Cs}_{2} \mathrm{CO}_{3}$. This Suzuki coupling strategy represents a useful method for the indirect ${ }^{18} \mathrm{~F}$ labeling of pharmaceuticals that could be applied to the synthesis of other PET tracers. The in vivo evaluation of $\left[{ }^{18} \mathrm{~F}\right]$ pitavastatin using PET is currently underway in our laboratory, and the results of these experiments will be published elsewhere in due course. 


\section{Experimental}

\section{Chemistry}

\section{General Methods}

All of the reagents and solvents used in the current study were purchased from Wako Pure Chemical Industries (Tokyo, Japan), Nacalai Tesque (Kyoto, Japan), Merck (Darmstadt, Germany) and Sigma Aldrich (St. Louis, MO, USA), and used without purification. Optical rotations were measured on an AUTOPOL IV system (Rudolph Research Analytical, Hackettstown, NJ, USA). ${ }^{1} \mathrm{H}$ NMR spectra were recorded on a JEOL ECA-500 spectrometer (JEOL, Tokyo, Japan) and the peaks referenced relative to the residual $\mathrm{CHCl}_{3}$ signal. Chemical shifts have been reported in parts per million (ppm) using the residual solvent peak as an internal standard. The ${ }^{1} \mathrm{H}$ NMR spectra have been tabulated as follows: chemical shift, multiplicity ( $\mathrm{br}=$ broad, $\mathrm{s}=$ singlet, $\mathrm{d}=$ doublet, $\mathrm{t}=$ triplet, quint $=$ quintet, sept $=$ septet, $\mathrm{m}=$ multiplet $)$, number of protons and coupling constant $(J)$. LRMS and HRMS analyses were conducted on JEOL JMS-SX 102A QQ and JEOL JMS-GC-mate mass spectrometer systems, respectively. Purifications by column chromatography were conducted over silica gel 60N (mesh size 63-210 $\mu \mathrm{m}$; Kanto Chemical Co., Inc., Tokyo, Japan). Thin-layer chromatography (TLC) was performed using Merck silica gel F-254 aluminum plates, which were visualized under 
UV light (254 nm). High performance liquid chromatography (HPLC) purifications and analyses were performed on a Shimadzu system (LC-10AT pump with an SPD-10A UV detector operating at 220 and 254 nm, Shimadzu Corporation, Kyoto, Japan) equipped with Cosmosil 5C18-ARII columns $(10 \times 250 \mathrm{~mm}$ and $4.6 \times 150 \mathrm{~mm}$, respectively; Nacalai Tesque Inc., Kyoto, Japan) and a radioisotope detector. Experiments conducted under microwave heating conditions were performed in a resonant-type microwave reactor, which was developed by SAIDA Inc. (Shizuoka, Japan). ${ }^{[14]}$

\section{Methyl (4-amino-2-cyclopropylquinolin-3-yl)carboxylate (7)}

$\beta$-Keto ester 6 (16.6 g, $140 \mathrm{mmol}$ ) and tin (IV) chloride (73.3 g, $281 \mathrm{mmol}$ ) were slowly added to a solution of 2-aminobenzonitrile (5) (20.0 g, $140 \mathrm{mmol})$ in toluene (280 mL) under an argon atmosphere at $15{ }^{\circ} \mathrm{C}$, and the resulting mixture was heated at reflux for 3 h. The reaction was then cooled to room temperature and diluted with a saturated aqueous solution of $\mathrm{Na}_{2} \mathrm{SO}_{4}$ before being cooled to $0{ }^{\circ} \mathrm{C}$. The resulting precipitate was crushed into smaller pieces and filtered, and the filtrate was extracted with EtOAc. The organic layer was washed with brine and dried over $\mathrm{MgSO}_{4}$ before being concentrated in vacuo to give aminoquinoline 7 as a purple solid (28.5 g, $83.9 \%)$.

${ }^{1} \mathrm{H}$ NMR (500 MHz, $\left.\mathrm{CDCl}_{3}\right) \delta: 7.79(\mathrm{~d}, J=8.3 \mathrm{~Hz}, 1 \mathrm{H}), 7.68(\mathrm{~d}, J=8.3 \mathrm{~Hz}, 1 \mathrm{H}), 7.59$ 
(t, $J=8.3 \mathrm{~Hz}, 1 \mathrm{H}), 7.31(\mathrm{t}, J=8.3 \mathrm{~Hz}, 1 \mathrm{H}), 6.64(\mathrm{br}, 2 \mathrm{H}), 3.95(\mathrm{~s}, 3 \mathrm{H}), 2.62$ (tt, $J=8.0$,

$4.9 \mathrm{~Hz}, 1 \mathrm{H}), 1.24$ (qd, $J=4.9,2.6 \mathrm{~Hz}, 2 \mathrm{H}), 0.94$ (dq, $J=8.0,2.6 \mathrm{~Hz}, 2 \mathrm{H}) ;{ }^{13} \mathrm{C} \mathrm{NMR}$

(125 MHz, $\left.\mathrm{CDCl}_{3}\right): \delta 170.0,161.9,152.3,147.7,130.8,129.2,124.4,120.4,116.6$, 103.5, 51.7, 17.2, 9.4 (2C); MS (EI) m/z: 242 (M+1, 100), 214 (98), 209 (76), 183 (86), 171 (30), 154 (28); HRMS calcd for $\mathrm{C}_{14} \mathrm{H}_{14} \mathrm{~N}_{2} \mathrm{O}_{2}\left(\mathrm{M}^{+}\right)$: 242.1055, found 242.1060.

\section{Methyl (4-bromo-2-cyclopropylquinolin-3-yl)carboxylate (8)}

Copper (I) bromide (29.5 g, $206 \mathrm{mmol})$ and tert-butyl nitrite (18.2 g, $176 \mathrm{mmol})$ were slowly added to a solution of aminoquinoline 7 (28.5 g, $117 \mathrm{mmol})$ in $\mathrm{MeCN}$ (280 mL) under an argon atmosphere at $15^{\circ} \mathrm{C}$, and the resulting mixture was stirred at $40{ }^{\circ} \mathrm{C}$ for $2.5 \mathrm{~h}$. The mixture was then cooled to room temperature and stirred for overnight. The reaction mixture was diluted with a saturated aqueous solution of $\mathrm{Na}_{2} \mathrm{SO}_{4}$, and the resulting precipitate was removed by filtration. The filtrate was extracted with EtOAc, and the organic layer was washed with brine and dried over $\mathrm{MgSO}_{4}$. The solvent was then removed under reduced pressure to give a residue, which was purified by column chromatography over silica gel eluting with a 20:1 (v/v) mixture of $n$-hexane and EtOAc to give bromide 8 as an orange solid (20.9 g, $58.0 \%)$.

${ }^{1} \mathrm{H}$ NMR (500 MHz, $\mathrm{CDCl}_{3}$ ) $\delta: 8.11$ (d, $\left.J=8.3 \mathrm{~Hz}, 1 \mathrm{H}\right), 7.90(\mathrm{~d}, J=8.3 \mathrm{~Hz}, 1 \mathrm{H}), 7.68$ (t, $J=8.3 \mathrm{~Hz}, 1 \mathrm{H}), 7.52$ (t, $J=8.3 \mathrm{~Hz}, 1 \mathrm{H}), 4.05$ (s, 3H), 2.06 (tt, $J=8.0,4.6 \mathrm{~Hz}, 1 \mathrm{H})$, 
1.24 (qd, $J=4.6,2.9 \mathrm{~Hz}, 2 \mathrm{H}), 0.94$ (dq, $J=8.0,2.9 \mathrm{~Hz}, 2 \mathrm{H}) ;{ }^{13} \mathrm{C}$ NMR $(125 \mathrm{MHz}$, $\left.\mathrm{CDCl}_{3}\right): \delta 167.8,158.7,150.8,130.8,130.7,130.4,129.2,127.0,126.9,125.1,53.0$, 15.8, 10.7 (2C); MS (EI) m/z: 307 (M+2, 66), 305 (M+',68), 277 (100), 262 (39), 246 (91), 226 (19), 167 (90); HRMS calcd for $\mathrm{C}_{14} \mathrm{H}_{12} \mathrm{BrNO}_{2}\left(\mathrm{M}^{+}\right)$: 305.00509, found 305.00583.

\section{(4-Bromo-2-cyclopropylquinolin-3-yl)carbaldehyde (4)}

A 1.0 M solution of DIBAL in $n$-hexane $(20.8 \mathrm{~mL}, 20.8 \mathrm{mmol})$ was added to a solution of bromide 8 (3.19 g, $10.4 \mathrm{mmol}$ ) in toluene (20.0 mL) under an argon atmosphere at $0{ }^{\circ} \mathrm{C}$, and the resulting mixture was stirred for $1 \mathrm{~h}$ at room temperature. The reaction was then cooled to $0{ }^{\circ} \mathrm{C}$ and quenched by the addition of a $5 \%$ solution of $\mathrm{H}_{2} \mathrm{SO}_{4}$. The resulting mixture was extracted with EtOAc, and the organic layer was washed with brine and dried over $\mathrm{MgSO}_{4}$. The solvent was then removed under reduced pressure to give alcohol 8a as a brown solid (2.30 g).

${ }^{1} \mathrm{H}$ NMR (500 MHz, $\mathrm{CDCl}_{3}$ ) $\delta: 8.10$ (d, $\left.J=8.2 \mathrm{~Hz}, 1 \mathrm{H}\right), 7.89(\mathrm{~d}, J=8.2 \mathrm{~Hz}, 1 \mathrm{H}), 7.64$ (t, $J=7.5 \mathrm{~Hz}, 1 \mathrm{H}), 7.48$ (t, $J=7.5 \mathrm{~Hz}, 1 \mathrm{H}), 5.23(\mathrm{~s}, 2 \mathrm{H}), 2.53(\mathrm{tt}, J=8.0,4.2 \mathrm{~Hz}, 1 \mathrm{H})$, 2.27 (br, $1 \mathrm{H}$ ), 1.29 (qd, $J=4.2,3.1 \mathrm{~Hz}, 2 \mathrm{H}), 1.06$ (dq, $J=8.2,3.1 \mathrm{~Hz}, 2 \mathrm{H}) ;{ }^{13} \mathrm{C} \mathrm{NMR}$

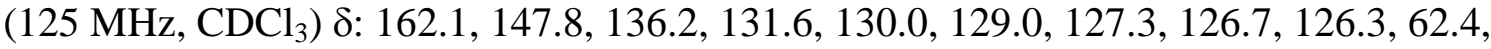


14.2, 11.5 (2C); MS (EI) m/z: 279 (M+2, 87), 277 (M+, 89), 260 (100), 248 (24), 179

(37), 167 (49); HRMS calcd for $\mathrm{C}_{13} \mathrm{H}_{12} \mathrm{BrNO}\left(\mathrm{M}^{+}\right)$: 277.0102, found 277.0096.

Dess-Martin periodinane (1.68 g, $3.95 \mathrm{mmol})$ was added to a solution of alcohol $8 \mathbf{a}$ (1.00 g, $3.60 \mathrm{mmol})$ in $\mathrm{CH}_{2} \mathrm{Cl}_{2}(20.0 \mathrm{~mL})$ under an argon atmosphere at $0{ }^{\circ} \mathrm{C}$, and the resulting mixture was stirred for $3 \mathrm{~h}$ at room temperature. The reaction was then quenched by the addition of a saturated aqueous solution of $\mathrm{NaHCO}_{3}$, and the resulting mixture was extracted with EtOAc. The organic layer was washed sequentially with a saturated aqueous solution of $\mathrm{NaS}_{2} \mathrm{O}_{3}$ and brine and dried over $\mathrm{MgSO}_{4}$. The solvent was then removed under reduced pressure to give a residue, which was purified by column chromatography over silica gel eluting with a 10:1 (v/v) mixture of $n$-hexane and EtOAc to give aldehyde 4 as a colorless solid (830 mg, $83.6 \%$ in 2 steps).

${ }^{1} \mathrm{H}$ NMR (500 MHz, $\mathrm{CDCl}_{3}$ ) $\delta: 10.7$ (s, 1H), 8.25 (d, $\left.J=8.2 \mathrm{~Hz}, 1 \mathrm{H}\right), 7.89$ (d, $J=8.2$ Hz, 1H), 7.76 (t, $J=8.2 \mathrm{~Hz}, 1 \mathrm{H}), 7.56$ (t, $J=8.2 \mathrm{~Hz}, 1 \mathrm{H}), 3.02$ (tt, $J=8.2,4.2 \mathrm{~Hz}, 1 \mathrm{H})$, 1.24 (qd, $J=4.2,3.1 \mathrm{~Hz}, 2 \mathrm{H}), 0.94(\mathrm{dq}, J=8.2,3.1 \mathrm{~Hz}, 2 \mathrm{H}) ;{ }^{13} \mathrm{C}$ NMR (125 MHz, $\left.\mathrm{CDCl}_{3}\right) \delta:$ 194.0, 162.1, 149.0, 140.8, 132.5, 129.2, 127.2, 127.0, 126.8, 125.5, 14.2, 11.5 (2C); MS (EI) m/z: 277 (M+2, 8.6), 275 (M+, 8.6), 247 (100), 196 (1.3), 168 (2.8); HRMS calcd for $\mathrm{C}_{13} \mathrm{H}_{10} \mathrm{BrNO}\left(\mathrm{M}^{+}\right)$: 274.9945, found 274.9939 . 


\section{Methyl (3R, 6E)-7-(4-bromo-2-cyclopropylquinolin-3-yl)-3-(tert-butyldimethyl-}

\section{silyloxy)-5-oxohept-6-enoate (9)}

A solution of phosphonate $3(7.00 \mathrm{~g}, 18.3 \mathrm{mmol})$ in THF $(48.0 \mathrm{~mL})$ was added to a suspension of sodium hydride (0.730 g, $18.2 \mathrm{mmol}, 60 \%$ dispersion in mineral oil) in THF (12.5 mL) under an argon atmosphere at $0{ }^{\circ} \mathrm{C}$, and the resulting mixture was stirred for $1 \mathrm{~h}$ at $0{ }^{\circ} \mathrm{C}$. A solution of aldehyde 4 (4.81 g, $\left.17.4 \mathrm{mmol}\right)$ in THF (75.0 mL) was then added to the reaction at $0{ }^{\circ} \mathrm{C}$, and the resulting mixture was stirred for overnight at room temperature. The reaction was then quenched by the addition of a saturated aqueous solution of $\mathrm{NH}_{4} \mathrm{Cl}$, and the resulting mixture was extracted with EtOAc. The organic layer was washed with brine and dried over $\mathrm{Na}_{2} \mathrm{SO}_{4}$. The solvent was removed under reduced pressure to give a residue, which was purified by column chromatography over silica gel eluting with a 5:1 (v/v) mixture of $n$-hexane and EtOAc to give alkene 9 as a yellow oil (8.57 g, $92.5 \%)$.

${ }^{1} \mathrm{H}$ NMR (500 MHz, $\mathrm{CDCl}_{3}$ ) $\delta: 8.16(\mathrm{~d}, J=8.3 \mathrm{~Hz}, 1 \mathrm{H}), 7.91(\mathrm{~d}, J=16.3 \mathrm{~Hz}, 1 \mathrm{H}), 7.90$ (d, $J=8.3 \mathrm{~Hz}, 1 \mathrm{H}), 7.68$ (t, $J=8.3 \mathrm{~Hz}, 1 \mathrm{H}), 7.53(\mathrm{t}, J=8.3 \mathrm{~Hz}, 1 \mathrm{H}), 6.71$ (d, $J=16.3$ Hz, 1H), 4.76 (m, 1H), 3.70 (s, 3H), 3.06 (dd, $J=15.8,6.9 \mathrm{~Hz}, 1 \mathrm{H}), 2.97$ (dd, $J=15.8$, $5.7 \mathrm{~Hz}, 1 \mathrm{H}), 2.65$ (dd, $J=14.7,5.7 \mathrm{~Hz}, 1 \mathrm{H}), 2.59$ (dd, $J=14.7,6.3 \mathrm{~Hz}, 1 \mathrm{H}), 2.30$ (tt, $J$ = 8.0, 4.6 Hz, 1H), 1.35 (dq, $J=4.6,3.0 \mathrm{~Hz}, 2 \mathrm{H}), 1.05(\mathrm{dq}, J=8.0,3.0 \mathrm{~Hz}, 2 \mathrm{H}), 0.85$ (s, 
9H), 0.10 (s, 3H), 0.09 (s, 3H); ${ }^{13} \mathrm{C}$ NMR (125 MHz, $\left.\mathrm{CDCl}_{3}\right): \delta$ 197.5, 171.4, 160.1, 147.5, 140.4, 135.0, 134.7, 130.5, 129.8, 129.1, 127.0 (2C), 126.9, 125.9, 66.1, 51.5, 48.2, 42.5, 25.7 (3C), 17.9, 16.5, 11.0, -4.7, -4.9; MS (CI) m/z: 534 (M+2, 100), 532 (M+ $\left.\mathrm{M}^{+}, 96\right), 474$ (50), 400 (39), 320 (32), 217 (39), 133 (41), 75 (41); HRMS calcd for $\mathrm{C}_{26} \mathrm{H}_{34} \mathrm{BrNO}_{4} \mathrm{Si}\left(\mathrm{M}^{+}\right)$: 532.1518, found 532.1515; $[\alpha]^{20}{ }_{\mathrm{D}}:+1.685$ (c 0.99, $\left.\mathrm{MeOH}\right)$.

\section{Methyl (3R, 6E)-7-(4-bromo-2-cyclopropylquinolin-3-yl)-3-hydroxy-5-oxohept-6-} enoate (10)

A 1:19 (v/v) solution of $48 \%$ hydrofluoric acid in MeCN (4.00 mL) was added to a solution of alkene $9(400 \mathrm{mg}, 0.751 \mathrm{mmol})$ in $\mathrm{MeCN}(1.00 \mathrm{~mL})$ at $0{ }^{\circ} \mathrm{C}$, and the resulting mixture was stirred for $19 \mathrm{~h}$ at room temperature. The reaction was then quenched by the addition of an aqueous solution of $\mathrm{NaHCO}_{3}$, and the resulting mixture was extracted with EtOAc. The organic layer was washed with brine and dried over $\mathrm{MgSO}_{4}$. The solvent was removed under reduced pressure to give a residue, which was purified by column chromatography over silica gel eluting with a 2:1 (v/v) mixture of n-hexane and EtOAc to give $\beta$-hydroxy ester 10 as a yellow solid (280 mg, $89.1 \%$ ).

${ }^{1} \mathrm{H}$ NMR (500 MHz, $\mathrm{CDCl}_{3}$ ) $\delta: 8.15(\mathrm{~d}, J=8.3 \mathrm{~Hz}, 1 \mathrm{H}), 7.93(\mathrm{~d}, J=16.6 \mathrm{~Hz}, 1 \mathrm{H}), 7.90$ (d, $J=8.3 \mathrm{~Hz}, 1 \mathrm{H}), 7.68(\mathrm{t}, J=8.3 \mathrm{~Hz}, 1 \mathrm{H}), 7.53(\mathrm{t}, J=8.3 \mathrm{~Hz}, 1 \mathrm{H}), 6.71(\mathrm{~d}, J=16.6$ 
Hz, 1H), 4.65 (br, 1H), 3.74 (s, 3H), 3.53 (br, 1H), 3.05 (dd, $J=17.1,7.4$ Hz, 1H), 3.00

(dd, $J=17.1,4.4 \mathrm{~Hz}, 1 \mathrm{H}), 2.65$ (d, $J=6.6 \mathrm{~Hz}, 2 \mathrm{H}), 2.28$ (tt, $J=8.0,4.6 \mathrm{~Hz}, 1 \mathrm{H}$ ), 1.35

(dq, $J=4.6,3.1 \mathrm{~Hz}, 2 \mathrm{H}), 1.05$ (dq, $J=8.0,3.1 \mathrm{~Hz}, 2 \mathrm{H}) ;{ }^{13} \mathrm{C}$ NMR $\left(125 \mathrm{MHz}, \mathrm{CDCl}_{3}\right): \delta$

198.6, 172.2, 160.1, 147.5, 141.0, 134.8, 134.4, 130.6, 129.5, 129.0, 127.0 (2C), 125.8,

64.5, 51.5, 46.4, 40.6, 16.5, 11.0 (2C); MS (EI) m/z: 419 (M+2, 0.1), 417 (M+ 0.1), 315

(22), 236 (100), 102 (3.0), 74 (3.0); HRMS calcd for $\mathrm{C}_{20} \mathrm{H}_{20} \mathrm{BrNO}_{4}\left(\mathrm{M}^{+}\right)$: 417.0575, found $417.0583 ;[\alpha]_{\mathrm{D}}^{20}:-7.727(c 0.99, \mathrm{MeOH})$.

Methyl (3R, 5S, 6E)-7-(4-bromo-2-cyclopropylquinolin-3-yl)-3,5-

\section{dihydroxyhept-6-enoate (11)}

A 1.0 M solution of diethylmethoxyborane in THF $(10.8 \mathrm{~mL}, 10.8 \mathrm{mmol})$ was added to a solution of $\beta$-hydroxy ester 10 (4.03 g, $9.63 \mathrm{mmol})$ in THF (30.0 mL) and $\mathrm{MeOH}$ $(6.00 \mathrm{~mL})$ at $-78^{\circ} \mathrm{C}$, and the resulting mixture was stirred for $20 \mathrm{~min}$ at $-78{ }^{\circ} \mathrm{C}$. Sodium borohydride (452 mg, $10.7 \mathrm{mmol}$ ) was then added to the reaction mixture at $-78{ }^{\circ} \mathrm{C}$, and the resulting mixture was stirred for $1 \mathrm{~h}$ at $-78{ }^{\circ} \mathrm{C}$. The reaction was then quenched by the addition of a solution of $\mathrm{AcOH}(5.70 \mathrm{~mL})$ in EtOAc $(27.0 \mathrm{~mL})$, and the resulting mixture was stirred for $3 \mathrm{~h}$ at room temperature. The mixture was poured into a saturated aqueous solution of $\mathrm{NaHCO}_{3}$, and the resulting mixture was extracted with 
EtOAc. The organic layer was washed with brine and dried over $\mathrm{MgSO}_{4}$ before being concentrated under reduced pressure. The resulting residue was purified by column chromatography over silica gel eluting with a 1:1 (v/v) mixture of $n$-hexane and EtOAc to give diol 11 as a yellow solid (2.93 g, $72.0 \%)$.

${ }^{1} \mathrm{H}$ NMR (500 MHz, $\left.\mathrm{CDCl}_{3}\right) \delta: 8.13(\mathrm{~d}, J=8.0 \mathrm{~Hz}, 1 \mathrm{H}), 7.88(\mathrm{~d}, J=8.2 \mathrm{~Hz}, 1 \mathrm{H}), 7.63$ (t, $J=8.2 \mathrm{~Hz}, 1 \mathrm{H}), 7.49$ (t, $J=8.2 \mathrm{~Hz}, 1 \mathrm{H}), 6.87$ (dd, $J=16.0,1.1 \mathrm{~Hz}, 1 \mathrm{H}), 6.09$ (dd, $J$ = 16.0, $5.7 \mathrm{~Hz}, 1 \mathrm{H}), 4.73(\mathrm{br}, 1 \mathrm{H}), 4.42(\mathrm{br}, 1 \mathrm{H}), 3.81(\mathrm{~s}, 1 \mathrm{H}), 3.73(\mathrm{~s}, 3 \mathrm{H}), 3.63(\mathrm{~s}, 1 \mathrm{H})$, 2.57 (dd, $J=6.8,1.7 \mathrm{~Hz}, 2 \mathrm{H}), 2.42$ (tt, $J=8.0,4.6 \mathrm{~Hz}, 1 \mathrm{H}), 1.91-1.80$ (m, 2H), 1.29 (dd, $J=4.6,2.6 \mathrm{~Hz}, 2 \mathrm{H}), 1.01(\mathrm{dq}, J=8.0,2.6 \mathrm{~Hz}, 2 \mathrm{H}) ;{ }^{13} \mathrm{C} \mathrm{NMR}\left(125 \mathrm{MHz}, \mathrm{CDCl}_{3}\right): \delta$ 172.9, 160.9, 147.0, 140.0, 133.8, 131.8, 129.5, 127.0 (2C), 126.6, 126.5, 126.2, 72.4, 68.4, 51.9, 42.4, 41.4, 16.4, 10.7 (2C); MS (EI) m/z: 421 (M+2, 3.2), 419 (M+ 3.3), 383 (7.5), 340 (38), 298 (45), 274 (100), 220 (56); HRMS calcd for $\mathrm{C}_{20} \mathrm{H}_{22} \mathrm{BrNO}_{4}\left(\mathrm{M}^{+}\right)$: 419.0732, found 419.0729; $[\alpha]^{20}{ }_{\mathrm{D}}:+22.858($ ( $1.00, \mathrm{MeOH})$.

Methyl (3R, 5S, 6E)-7-\{2-cyclopropyl-4-(4,4,5,5-tetramethyl-1,3dioxabolan-2-yl)quinolin-3-yl\}-3,5-dihydroxyhept-6-enoate (2)

$\mathrm{PdCl}_{2}(\mathrm{dppf}) \mathrm{CH}_{2} \mathrm{Cl}_{2}(0.19 \mathrm{~g}, 0.240 \mathrm{mmol})$ was added to a stirred solution of diol $\mathbf{1 1}$ (1.00 g, $2.40 \mathrm{mmol})$, bis(pinacolato)diboron (12) (0.790 g, $3.12 \mathrm{mmol})$ and $\mathrm{K}_{2} \mathrm{CO}_{3}(1.00$ 
g, $7.20 \mathrm{mmol})$ in DMSO (40.0 $\mathrm{mL})$ under an argon atmosphere, and the resulting mixture was stirred for $4 \mathrm{~h}$ at $70{ }^{\circ} \mathrm{C}$. Silica gel was then added to the reaction, and the resulting mixture was filtrated through Celite. The filtrate was extracted with EtOAc and the organic layer was washed sequentially with water and brine before being dried over $\mathrm{Na}_{2} \mathrm{SO}_{4}$. The solvent was then concentrated under reduced pressure to give a residue, which was subjected to azeotropic dehydration with MeCN and purified by HPLC (Shimadzu system equipped with a Cosmosil 5C18-ARII $10 \times 250 \mathrm{~mm}$ column, MeCN/water $=50 / 50$, flow rate $=5.0 \mathrm{~mL} / \mathrm{min}$ ) to afford a brown oil. Powderization of the resulting oil with a 1:1 (v/v) mixture of diisopropyl ether and $n$-heptane gave boronate 2 as a pale yellow solid (0.290 g, $25.9 \%)$.

${ }^{1} \mathrm{H}$ NMR (500 MHz, $\mathrm{CDCl}_{3}$ ) $\delta: 7.91(\mathrm{~d}, J=9.2 \mathrm{~Hz}, 1 \mathrm{H}), 7.89$ (d, $\left.J=9.2 \mathrm{~Hz}, 1 \mathrm{H}\right), 7.56$ (t, $J=9.2 \mathrm{~Hz}, 1 \mathrm{H}), 7.40$ (t, $J=9.2 \mathrm{~Hz}, 1 \mathrm{H}), 7.19$ (dd, $J=16.0,1.4 \mathrm{~Hz}, 1 \mathrm{H}), 6.03$ (dd, $J$ = 16.0, $5.4 \mathrm{~Hz}, 1 \mathrm{H}), 4.66$ (br, 1H), 4.38 (br, 1H), 3.75 (br, 1H), 3.73 (s, 3H), 3.32 (br, 1H), $2.56(\mathrm{~d}, J=3.4 \mathrm{~Hz}, 1 \mathrm{H}), 2.54(\mathrm{~s}, 1 \mathrm{H}), 2.28(\mathrm{tt}, J=8.0,4.6 \mathrm{~Hz}, 1 \mathrm{H}), 1.87-1.78(\mathrm{~m}$, 2H), 1.46 (s, 12H), 1.25-1.20 (m, 2H), 0.98 (dd, $J=8.0,3.1 \mathrm{~Hz}, 2 \mathrm{H}) ;{ }^{13} \mathrm{C}$ NMR (125 $\left.\mathrm{MHz}, \mathrm{CDCl}_{3}\right): \delta 172.9,159.6,146.3,138.2,135.6,129.2,128.9(2 \mathrm{C}), 128.4,127.2(2 \mathrm{C})$, 125.4, 84.7 (2C), 72.4, 68.5, 51.9, 42.7, 41.3, 25.3 (2C), 25.2 (2C), 15.4, 9.5, 9.3; MS (EI) m/z: 467 (M+, 6.8), 346 (100), 322 (80), 220 (92), 206 (57); HRMS calcd for 
$\mathrm{C}_{26} \mathrm{H}_{34} \mathrm{BNO}_{6}\left(\mathrm{M}^{+}\right)$: 467.2479, found 467.2481; $[\alpha]^{20}{ }_{\mathrm{D}}:+22.932$ (c 1.00, MeOH).

\section{Methyl (3R, 5S, 6E)-7-\{2-cyclopropyl-4-(4-fluorophenyl)quinolin-3-yl\}-3,5-}

\section{dihydroxyhept-6-enoate (13)}

$\mathrm{Pd}\left(\mathrm{PPh}_{3}\right)_{4}(9.10 \mathrm{mg}, 0.00789 \mathrm{mmol})$ and $\mathrm{PdCl}_{2}(\mathrm{dppf}) \mathrm{CH}_{2} \mathrm{Cl}_{2}(6.20 \mathrm{mg}, 0.00789 \mathrm{mmol})$

were added to a solution of 2 (37.0 mg, $0.0788 \mathrm{mmol}$ ), 4-fluoroiodobenzene (26.2 $\mathrm{mg}$, $0.118 \mathrm{mmol})$, and $\mathrm{Na}_{2} \mathrm{CO}_{3}(25.0 \mathrm{mg}, 0.236 \mathrm{mmol})$ in DMSO (40.0 mL) under an argon atmosphere, and the resulting mixture was stirred for $9 \mathrm{~h}$ at $90^{\circ} \mathrm{C}$. The mixture was then cooled to room temperature, poured into water and extracted with EtOAc. The organic layer was washed with brine and dried over $\mathrm{Na}_{2} \mathrm{SO}_{4}$ before being concentrated under reduced pressure. The resulting residue was subjected to azeotropic dehydration with MeCN and purified by HPLC (Shimadzu system with a Cosmosil 5C18-ARII $10 \times 250$ $\mathrm{mm}$ column, $\mathrm{MeCN} /$ water $=70 / 30$, flow rate $=5.0 \mathrm{~mL} / \mathrm{min}$ ) to give methyl ester 13 as an amorphous solid (3.00 mg, $8.80 \%$ (isolated yield)).

${ }^{1} \mathrm{H}$ NMR (500 MHz, $\left.\mathrm{CDCl}_{3}\right) \delta: 7.95(\mathrm{~d}, J=8.3 \mathrm{~Hz}, 1 \mathrm{H}), 7.59$ (t, $\left.J=8.3 \mathrm{~Hz}, 1 \mathrm{H}\right), 7.35-$ 7.28 (m, 2H), 7.24-7.13 (m, 4H), 6.63 (dd, $J=16.0,1.4 \mathrm{~Hz}, 1 \mathrm{H}$ ), 5.58 (dd, $J=16.0,6.3$ Hz, 1H), 4.40 (m, $J=2.6 \mathrm{~Hz}, 1 \mathrm{H}), 4.15-4.10$ (m, 1H), 3.60 (br, 1H), 3.73 (s, 3H), 3.10 (br, 1H), 2.50-2.36 (m, 3H), 1.50 (ddd, $J=9.2,4.0,1.1 \mathrm{~Hz}, 1 \mathrm{H}), 1.37-1.30$ (m, 3H), 
0.98 (dd, $J=8.0,2.3 \mathrm{~Hz}, 2 \mathrm{H}) ;{ }^{13} \mathrm{C}$ NMR (125 MHz, $\left.\mathrm{CDCl}_{3}\right): \delta 172.9,162.2\left(\mathrm{~d}, J_{\mathrm{F}}=\right.$ $246.5 \mathrm{~Hz}), 161.2,160.7,146.8,144.2,139.7,133.5,131.8$ (dd, $\left.J_{\mathrm{F}}=28.8,7.8 \mathrm{~Hz}\right)(2 \mathrm{C})$, 129.3, 128.9, 126.1, 126.0, 125.8, 125.4, 115.3 (dd, $\left.J_{\mathrm{F}}=21.6,3.3 \mathrm{~Hz}\right)(2 \mathrm{C}), 72.4,68.0$, 51.9, 42.3, 41.2, 15.9, 10.3, 10.2; MS (EI) m/z: 435 (M+1, 5.2), 314 (56), 280 (100), 274 (70), 220 (14); HRMS calcd for $\mathrm{C}_{26} \mathrm{H}_{26} \mathrm{FNO}_{4}\left(\mathrm{M}^{+}\right)$: 435.1846, found 435.1849; $[\alpha]^{20}$ : +35.707 ( 0.68, $\mathrm{MeOH}$ ).

(3R, 5S, 6E)-7-[2-cyclopropyl-4-\{4-fluorophenyl\}quinolin-3-yl]-3,5-dihydroxyhept-

\section{6-enoic acid (pitavastatin)}

A 1.0 M aqueous solution of $\mathrm{NaOH}(1 \mathrm{~mL})$ was added to a solution of $\mathbf{1 3}$ (3 $\mathrm{mg}, 6.9$ $\mu \mathrm{mol})$ in methanol $(1 \mathrm{~mL})$ at room temperature, and the resulting mixture was stirred for $30 \mathrm{~min}$ at the same temperature. The reaction mixture was then concentrated under reduced pressure to give pitavastatin (sodium salt) as a colorless oil (3 mg, quant.). ${ }^{1} \mathrm{H}$ NMR (500 MHz, DMSO-d6) $\delta: 7.83$ (d, $\left.J=8.3 \mathrm{~Hz}, 1 \mathrm{H}\right), 7.60$ (t, $\left.J=8.3 \mathrm{~Hz}, 1 \mathrm{H}\right)$, 7.36-7.23 (m, 6H), 6.48 (d, $J=16.0 \mathrm{~Hz}, 1 \mathrm{H}), 5.80$ (br, 1H), 5.57 (dd, $J=16.0,5.5 \mathrm{~Hz}$, 1H), 4.93 (br, 1H), 4.13 (m, 1H), 3.65 (br, 1H), 3.40 (m, 4H), 2.08 (d, $J=12.0 \mathrm{~Hz}, 1 \mathrm{H})$, 1.95 (dd, $J=15.5,8.6 \mathrm{~Hz}, 1 \mathrm{H}), 1.40$ (dt, $J=14.3,7.8 \mathrm{~Hz}, 1 \mathrm{H}), 1.20-1.00$ (m, 5H); ${ }^{13} \mathrm{C}$

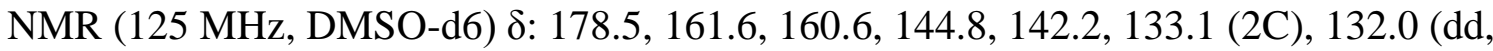


$J_{F}=37.4,8.0 \mathrm{~Hz}$ ) (2C), 129.6, 128.8, 128.3, 125.7, 125.6 (2C), 123.1, $115.2\left(\mathrm{dd}, J_{F}=\right.$ 21.0, $9.3 \mathrm{~Hz}$ ) (2C), 68.9, 65.6, 44.2, 40.0, 15.3, 10.7 (2C); MS (FAB+) m/z: $444\left(\mathrm{M}^{+}\right)$; HRMS (FAB + ) calcd for $\mathrm{C}_{25} \mathrm{H}_{26} \mathrm{FNO}_{4}$ : 422.1768, found 422.1762; $[\alpha]^{20}{ }_{\mathrm{D}}:+22.265(\mathrm{c}$ $\left.0.22, \mathrm{MeCN} / \mathrm{H}_{2} \mathrm{O}\right)$.

\section{Radiochemistry}

$\left[{ }^{18}\right.$ F]Fluoride was produced by cyclotron (CYPRIS HM-18, Sumitomo Heavy Industries, Tokyo, Japan) via an ${ }^{18} \mathrm{O}(\mathrm{p}, \mathrm{n}){ }^{18} \mathrm{~F}$ reaction and passed through a Sep-Pak Light QMA cartridge (Waters Corporation, Milford, MA, USA) as an aqueous solution in ${ }^{18} \mathrm{O}$-enriched water. The cartridge was dried under a stream of $\mathrm{N}_{2}$ and the ${ }^{18} \mathrm{~F}$ activity was eluted with $1.00 \mathrm{~mL}$ of a Kryptofix2.2.2 (Merck)/ $\mathrm{K}_{2} \mathrm{CO}_{3}$ solution (9.50 mg of Kryptofix2.2.2 and 1.70 $\mathrm{mg}$ of $\mathrm{K}_{2} \mathrm{CO}_{3}$ in 96:4 (v/v) mixture of $\mathrm{MeCN}$ and water). The solvent was removed by azeotropic dehydration with MeCN $(1.00 \mathrm{~mL})$ at $120^{\circ} \mathrm{C}$ under a stream of argon gas over $10 \mathrm{~min}$.

\section{Synthesis of $p$-[ $\left[{ }^{18}\right.$ F]fluoroiodobenzene $\left(\left[{ }^{18} F\right] 1\right)$ from 4-iodophenyldiphenyl- sulfonium triflate}

A solution of 4-iodophenyldiphenylsulfonium triflate (2.00 mg) in MeCN (150 $\mu \mathrm{L})$ was 
added to a reaction vessel containing the ${ }^{18} \mathrm{~F}$ activity $(1.10-1.50 \mathrm{GBq})$, and the reaction was heated for 1 min under microwave irradiation $(50.0 \mathrm{~W})$, The resulting mixture was cooled for 1 min and then passed through a Sep-Pak Light C18 column (Waters) and washed with water $(10 \mathrm{~mL})$. A stream of $\mathrm{N}_{2}$ gas was passed over the column for $10 \mathrm{sec}$, and $p-\left[{ }^{18} \mathrm{~F}\right]$ fluoroiodobenzene $\left(\left[{ }^{18} \mathrm{~F}\right] \mathbf{1}\right)$ was eluted with $\mathrm{MeCN}(500 \mu \mathrm{L})$. The eluent containing $\left[{ }^{18} \mathrm{~F}\right] \mathbf{1}$ was determined to be purified by HPLC analysis (RCY $56.2 \pm 3.1 \%$ decay corrected, data are the mean $\pm \operatorname{SD}(n=3))$.

\section{Synthesis of $\left[{ }^{18} \mathrm{~F}\right]$ pitavastatin using Suzuki coupling reaction with $\left[{ }^{18} \mathrm{~F}\right] 1$}

A solution of $\left[{ }^{18} \mathrm{~F}\right] \mathbf{1}$ in $\mathrm{MeCN}(37.0-74.0 \mathrm{MBq}, 100 \mu \mathrm{L})$ was added to a solution of 2 (2.0 mg), $\mathrm{Pd}_{2}(\mathrm{dba})_{3}(1.00 \mathrm{mg})$ and $\mathrm{Cs}_{2} \mathrm{CO}_{3}(4.00 \mathrm{mg})$ in $\mathrm{MeCN}(100 \mu \mathrm{L})$, and the resulting mixture was heated to $100{ }^{\circ} \mathrm{C}$ under microwave irradiation $(50.0 \mathrm{~W})$ for 1 min. The mixture was then passed through a COSMONICE(R) Filter (S) (0.45 $\mu \mathrm{m}$, 4mm) and purified by preparative HPLC [Cosmosil 5C18-ARII $10 \times 250 \mathrm{~mm}$ column, $\mathrm{MeOH} / 20 \mathrm{mM}$ phosphate buffer $(\mathrm{pH} 2.5)=70 / 30$, flow rate $5.0 \mathrm{~mL} / \mathrm{min}$ ] to give a solution of pure $\left[{ }^{18} \mathrm{~F}\right]$ pitavastatin $\left(\mathrm{Rt}=8.53 \mathrm{~min}, 12.1 \pm 3.0 \% \mathrm{RCY}\right.$ from $\left[{ }^{18} \mathrm{~F}\right]$ fluoride ion, data are the mean $\pm \mathrm{SD}(\mathrm{n}=3)$, specific activity was $>10.0 \mathrm{GBq} / \mu \mathrm{mol})$. 


\section{Acknowledgements}

This work was supported in part by the New Energy and Industrial Technology

Development Organization (NEDO). Crude phosphate 3 material was provided by Nissan Chemical Industries, Ltd, and Kowa Company, Ltd. We would also like to thank KNC Laboratories Co., Ltd. and Dr. Hidekazu Imahori. No other potential conflicts of interest relevant to this article have been reported.

\section{References}

1. (a) M. Reivich, D. kuhl, A. Wolf, J. Greenberg, M. Phelps, T. Ido, V Casella, J Fowler, E Hoffman, A Alavi, P Som and L Sokoloff, Circ. Res., 1979, 44, 127; (b) S. Choi, G. Golding, Z. Zhuang, W. Zhang, N. Lim, F. Hefti, T. Benedum, M. Kilbourn, D. Skovronsky and H. Kung, J. Nucl. Med., 2009, 50, 1887; (c) V. Camus, P. Payoux, L. Barré, B. Desgranges, T. Voisin, C. Tauber, R. Joie, M. Tafani, C. Hommet, G. Chételat, K. Mondon, V. Sayette, J. P. Cottier, E. Beaufils, M. J. Ribeiro, V. Gissot, E. Vierron, J. Vercouillie, B. Vellas, F. Eustache and D. Guilloteau, Eur. J. Nucl. Med. Mol. Imaging, 2012, 39, 621; (d) M. Koole, D. M. Lewis, C. Buckley, N. Nelissen, M. Vandenbulcke, D. J. Brooks, R. Vandenberghe and K. Van Laere, J. Nucl. Med., 2009, 50, 818; (e) H. Barthel, H. Gertz, S. Dresel, 
O. Peters, P. Bartenstein, K. Buerger, F. Hiemeyer, S. Wittemer-Rump, J. Seibyl, C.

Reininger and O. Sabri, Lancet Neurol., 2011, 10, 424.

2. (a) S. Purser, P. R. Moore, S. Swallow and V. Gouverneur, Chem. Soc. Rev., 2008, 37, 320; (b) H. J. Böhm, D. Banner, S. Bendels, M. Kansy, B. Kuhn, K. Müller, U. Obst-Sander and M. Stahl, Chem. Bio. Chem., 2004, 5, 637; (c) A. P. Degnan, P. V. Chaturvedula, C. M. Conway, D. A. Cook, C. D. Davis, R. Denton, X. Han, R. Macci, N. R. Mathias, P. Moench, S. S. Pin, S. X. Ren, R. Schartman, L. J. Signor, G. Thalody, K. A. Widmann, C. Xu, J. E. Macor and G. M. Dubowchik, J. Med. Chem., 2008, 51, 4858.

3. (a) V. W. Pike, C. Halldin, C. Crouzel, L. Barrüe, D. J. Nutt, S. Osman, F. Shah, D. R. Turton and S. L. Waters, Nucl. Med. Biol., 1993, 20, 503; (b) B. S. Moon, H. S. Kil, J. H. Park, J. S. Kim, J. Park, D. Yoon Chi, B. C. Lee and S. E. Kim, Org. Biomol. Chem., 2011, 9, 8346; (c) X. Fei, J.-Q. Wang, K. D. Miller, G. W. Sledge, G. D. Hutchins and Q.-H. Zheng, Nucl. Med. Biol., 2004, 31, 1033. (d) J. S. Perlmutter, M. K. Stambuk, J. Markham, K. J. Black, L. McGee-Minnich, J. Jankovic and S. M. Moerlein, J. Neurosci., 1997, 17, 843.

4. (a) T. Takashima, H. Nagata, T. Nakae, Y. Cui, Y. Wada, S. Kitamura, H. Doi, M. Suzuki, K. Maeda, H. Kusuhara, Y. Sugiyama and Y. Watanabe, J. Pharmacol. Exp. 
Ther., 2010, 335, 314. (b) T. Takashima, Y. Hashizume, Y. Katayama, M. Murai, Y. Wada, K. Maeda, Y. Sugiyama and Y. Watanabe, Mol. Pharmaceutics, 2011, 8, 1789. (c) R. Ijuin, T. Takashima, Y. Watanabe, Y. Sugiyama and M. Suzuki, Bioorg. Med. Chem., 2012, 20, 3703-3709. (d) J. He, Y. Yu, B. Prasad, J. Link, R. S. Miyaoka, X. Chen and J. D. Unadkat, Mol. Pharmaceutics, 2014, 11, 2745.

5. (a) H. Fujino, I. Yamada, J. Kojima, M. Hirano, H. Matsumoto and M. Yoneda, Xenobio. Metabol. And Dispos., 1999, 14, 415. (b) M. Hirano, K. Maeda, Y. Shitara and Y. Sugiyama, J. Pharmacol. Exp. Ther., 2004, 311, 139.

6. S. Banister, D. Roeda, F. Dollé and M. Kassiou, Current Radiopharmaceuticals, 2010, 3, 68

7. B. Wängler, S. Schneider, O. Thews, E. Schirrmacher, S. Comagic, P. Feilen, C. Schwanstecher, M. Schwanstecher, C.-Y. Shiue, A. Alavi, S. Höhnemann, M. Piel, F. Rösch and R. Schirrmacher, Nucl. Med. Biol., 2004, 31, 639.

8. (a) M. Tredwell and V. Gouverneur, Angew. Chem. Int. Ed., 2012, 51, 11426; (b) P. J. H. Scott and X. Shao, J. Label. Compd. Radiopharm., 2010, 53, 586; (c) U. Ackermann, S. D. Yeoh, J. I. Sachinidis, S. S. Poniger, A. M. Scott and H. J. Tochon-Danguy, J. Label. Compd. Radiopharm., 2011, 54, 671. 
9. (a) N. Miyaura and A. Suzuki, Chem. Rev., 1995, 95, 2457. (b) A. Suzuki, J. Organometal. Chem., 2002, 653, 83.

10. (a) M. Acemoglu, A. Brodbeck, A. Garcia , D. Grimler, M. Hassel, B. Riss and R. Schreiber, Helv. Chim. Acta, 2007, 90, 1069; (b) N. Miyachi, Y. Yanagawa, H. Iwasaki, Y. Ohara and T. Hiyama, Tetrahedron Lett., 1993, 34, 8267; (c) M. Suzuki, Y. Yanagawa, H. Iwasaki, H. Kanda, K. Yanagihara, H. Matsumoto, Y. Ohara, Y. Yazaki and R. Sakoda, Bioorg. Med. Chem. Lett., 1999, 9, 2977. (d) M. Suzuki, H. Iwasaki, Y. Fujikawa, M. Kitahara, M. Sakashita and R. Sakoda, Bioorg. Med. Chem., 2001, 9, 2727.

11. (a) R. H. Manske, Chem. Rev., 1942, 30 113; (b) F. W. Bergstrom, Chem. Rev., 1944, $35,77$.

12. D. S. Karanewsky, M. F. Malley and J. Z. Gougoutas, J. Org. Chem., 1991, 56, 3744.

13. L. Mu, C. R. Fischer, J. P. Holland, J. Becaud, P. A. Schubiger, R. Schibli, S. M. Ametamey, K. Graham, T. Stellfeld, L. M. Dinkelborg and L. Lehmann, Eur. J. Org. Chem., 2012, 2012, 889.

14. H. Kimura, Y. Yagi, N. Ohneda, H. Odajima, M. Ono and H. Saji, J. Label. Compd. 
Radiopharm. DOI: 10.1002/jlcr.3232, in press. 